\title{
Globalizing Allegory: Augusto Boal's A Lua Pequena e a Caminhada Perigosa in Brazil and Cape Verde
}

\section{Christina S. McMahon}

For an appreciation of the transcience of things, and the concern to rescue them for eternity, is one of the strongest impulses in allegory.

- Walter Benjamin ${ }^{1}$

1964-1965: O golpe veio a galope e também veio a pé. Cavalos e cavaleiros tomaram o poder e reforçam a censura. Tivemos de nos refugiar na história, nas fábulas.

- Augusto Boal ${ }^{2}$

Fazer teatro, em Cabo Verde,... foi, na realidade, o grande objectivo do grupo "Korda Kaoberdi"... Nesta ordem de ideias, era necessário provar que o teatro em Cabo Verde teria, sem dúvida, que existir consequentemente em termos autenticamente universais.

-Kwame Kondé

Must allegory always reference the nation? This is a pressing question raised by Fredric Jameson's polemical conclusion to "Third-World Literature in the Era of Multinational Capitalism." "In that essay, Jameson suggests that literature produced in the "third-world" always takes the form of national allegory, meaning that personal relationships necessarily reference the predicament of the state embroiled in a struggle with "first-world" imperialism (69). In an incisive response, Aijaz Ahmad critiques Jameson's essentialist view of the "third-world" and his homogenizing category "thirdworld literature." Issues of terminology aside, Jameson's essay makes a compelling case for the prevalence of political allegory in literature, which presumably extends to dramatic literature as well. Yet now is perhaps an 
appropriate time to re-evaluate Jameson's assumption that the political is always tied to a particular nation-state. In an age increasingly dominated by what Arjun Appadurai calls the expansion of the "social imagination" via various global flows of people (ethnoscapes), images (mediascapes), money (financescapes), technology (technoscapes), and ideologies (ideoscapes) (3133), literary or theatrical allegories are circulated more widely and rapidly than ever before, infusing allegory with the potential to gesture toward not just the national but the global.

I would like to offer as an example of global allegory Augusto Boal's play A Lua Pequena e a Caminhada Perigosa, ${ }^{5}$ a collage of texts and speeches by Ernesto "Che" Guevara, Fidel Castro and three Latin American poets. Penned in 1968, a year after Guevara's death and four years into Brazil's notoriously harsh military dictatorship, the play is ostensibly an homage to Guevara and his efforts at inciting revolution in Bolivia. The play's account of Guevara's personal experience with torture and execution by CIA-trained Bolivian soldiers can certainly be read as an allegory for political oppression under Brazilian military leaders brought to power in part through support from the U.S. government. ${ }^{6}$ Viewed in this way, A Lua seemingly fits Jameson's description of national allegory. I propose, however, that the play allegorizes Che as the human potential for socialist revolutions worldwide, so that Che's personal struggle represents not a national but a global resistance to imperialism. That the play participates in the global cultural economy is evidenced by a 1977 production on the Cape Verde islands, a small West African country just emerging from an eleven-year struggle against Portuguese colonialism. Cape Verde's revolution, waged jointly with GuineaBissau, was led by Amílcar Cabral, a Cape Verdean political theorist influenced by Guevara's ideology.

By employing the term "global allegory," I am not simply positing that $A$ Lua is a text with universal significance. Instead, I argue that global allegories address specific political situations in multiple countries simultaneously. The circulation of global allegories is particularly likely among countries experiencing what Brian Larkin has called "parallel modernities," or modernities outside of the Western paradigm that evidence similar "economic, religious, and cultural flows" (407-08). Larkin perceives parallel modernities within contemporary Indian Hindi culture and Nigerian Hausa communities; I apply the same concept to Brazil and Cape Verde in the 1960s and 70s, two Lusophone countries undergoing different variations of 
political turmoil. While Larkin explores how parallel modernities are created through film media, I consider how they may be nurtured through theatre.

According to the OED, the word "allegory" derives from the Greek words for "other" and "speaking." Thus, there is no reason to believe that an allegorist uses one metaphorical narrative to "speak" about only one "other" reality. Global allegories in fact function as ideoscapes, which Appadurai defines as narratives and images circulated widely around the globe, promoting either state ideologies or ideologies countering state power (36). In positioning $A L u a$ as a global allegory that disseminates a pan-socialist ideology, I draw from Walter Benjamin's explication of allegory as the moment when the transitory confronts the eternal (224). Che's personal struggle against imperialism may be transient but the circumstances of his death are eternally repeatable in any number of political climates analogous to that of Bolivia in 1967. To limit the possibilities of allegory to one context, the nation in which the allegorist happens to reside, overlooks the circulatory potential of political allegory. In essence, my formulation of global allegory is an attempt to extend Jameson's concept of national allegory to a globalized world in the same way that Appadurai's concept of a post-national social imagination builds upon Benedict Anderson's idea of the nation as an imagined community (Appadurai 21-22).

Jameson's notion of national allegory resonates with the kind of allegory admired by the Romantics, which Benjamin sought to challenge with his essay "Allegory and Trauerspiel." Benjamin critiques Johann Winckelmann's preference for allegory that "expresses the intended meaning in as few signs as possible" (qtd. on 186, my emphasis). Winckelmann's statement implies that there is one inherent signification of an allegorical narrative, even if brought about by multiple signifiers (albeit as few as possible). Although Jameson suggests that his perspective on allegory differs from the traditional reading of it as a "one-to-one table of equivalences," the example he proffers to illustrate this "multiple polysemia" is a short story by the twentiethcentury Chinese writer Lu Xun in which both the protagonist, Ah Q, and the bullies who antagonize him are allegories for China (73-74). In this example, a few signifiers bring about one ultimate signification, China. What Jameson overlooks about allegory is that the converse might also be true: one signifier could potentially generate multiple significations.

While the concept of national allegory restricts allegory to the boundaries of one nation-state, global allegories allow one allegory to apply to the changing states of multiple nations. Consider the case of $A$ Lua. Implicitly 
set in Bolivia but performed first in Brazil and later Cape Verde, the play pays tribute to a man born in Argentina but made famous for his instrumental role in bringing about the Cuban Revolution, as well as infamous for his thwarted attempts at fomenting revolution in the Congo and Bolivia. Further, among the collage of texts that make up the play are a passage from the Chilean poet Pablo Neruda's epic retelling of Latin American history, Canto General, and lyrical odes to Che from the Argentinian writers Julio Cortazar and Julio Huasi. Che is clearly allegorized in $A \mathrm{Lua}$, but considering his consummate example of internationalism (mirrored in the structure, setting, and production history of the play) it hardly seems tenable to assume that he represents only Brazil. Indeed, the situation that Che faced in Bolivia, where a government took drastic measures to quell the potential for a leftist revolution, was already being played out in Uruguay at the time of the play's publication in 1968, ${ }^{7}$ and would soon famously play out during Argentina's Dirty War (1976-83) and Pinochet's regime in Chile (1973-90). The 1960s was also the decade that the Portuguese government grew increasingly alarmed by Cuba-inspired revolutionary movements in its African colonies, led by Cabral in Cape Verde and Guinea-Bissau, Agostinho Neto in Angola, and Eduardo Mondlane in Mozambique.

While the text of $A \mathrm{Lua}$ is a striking example of global allegory, dramatic texts cannot be considered in isolation from their realizations as theatrical productions. In her reading of abstract allegory in Griselda Gambaro's play El despojamiento, Ana Elena Puga notes that allegories become more complex when staged as a response to specific political situations: "In the theatre, the actor's relationship with the spectator adds a performative dimension that even further complicates the allegory" (417). Drawing upon the political circumstances surrounding the stagings of $A$ Lua during the Feira de Opinião in São Paulo, Brazil, in 1968 and during Cape Verde's independence day celebrations in Mindelo in 1977, I consider the potential for theatrical productions to transform global allegories into national allegories. Further, I discuss the multiple ways that a global allegory can signify according to individual production contexts, so that the same political allegory can condemn one government, in the case of Brazil, and celebrate another, in the case of Cape Verde. The circulation of a text among theatre directors in various countries allows the meaning of a global allegory to shift with local stagings, so that the specific political climate of the country determines whether the government assumes the role of antagonist or protagonist in the allegory. 
Before proceeding, I wish to emphasize that this article is not an attempt to further canonize Boal. In his article "Theatre of the Oppressed and Teatro de Arena: In and Out of Context," David S. George critiques the tendency of North American scholars to read Boal uncritically by assuming his coringa ("joker") system is both original and liberating (40). George also raises significant questions about Boal's own writings about the Teatro de Arena, which tend to gloss over initiatives by José Renato and Gianfrancisco Guarnieri and obscure the fact that the Teatro de Arena was a collective endeavor (48). While George's criticism is sound, in this paper I am more concerned with the allegorical function of the coringa than its "liberating" potential or whether or not Boal borrowed the system from Bertolt Brecht (on this last point, I am inclined to agree with George) ${ }^{8}$ Likewise, whether or not theatre practitioners and scholars have misread Boal, it is the fact that they have read him that allows his dramatic texts to be circulated as global allegory. For better or worse, Boal's name was picked up in theatre circles worldwide while Renato's and Guarnieri's were not. It was Boal's curious international mystique that led to the "discovery" of A Lua in Cape Verde, and it is the potential for that global propulsion to induce shifts in the meaning of a theatrical allegory that this essay probes.

\section{A Lua Pequena e a Caminhada Perigosa as global allegory}

In characterizing $A L u a$ as global allegory, I am positing that the play is a departure from other plays written and directed by Boal during the same period that do function as national allegories. Boal's involvement with São Paulo's Teatro de Arena dates back to 1957 . The philosophy embraced by Boal and Teatro de Arena alike is that theatre should be artistically satisfying and politically effective, reflecting and responding to a Brazilian social reality. ${ }^{9}$ After the success of Guarnieri's play Eles Não Usam Black-Tie (1958), whose political vibrancy signaled a new palette for Arena's theatre (Milaré 20), Boal initiated a Seminário de Dramaturgia, which provided a forum for Brazilian writers such as Roberto Freire, Edy Lima, and Boal himself to create national texts to be showcased at the Teatro de Arena. ${ }^{10}$ Then, in April of 1964, President João Goulart was deposed in a military coup and Marshal Humberto de Alencar Castello Branco took power, ushering in a period of repression that Boal claims to have predicted in his play $O$ Golpe a Galope, referenced in the second epigraph above.

As a response to government censorship, Boal's plays became more allegorical, drawing upon figures from Brazil's history to comment upon con- 
temporary political circumstances. With Francisco Guarnieri in 1965, Boal penned Arena Conta Zumbi, which, as its title suggests, tells the story of the historical-turned-mythical figure Zumbi, the seventeenth-century Afro-Brazilian leader of Palmares, the free black republic in northeastern Brazil that was eventually overthrown by the Portuguese despite a number of heroic counterattacks staged by Zumbi (Meade 59). Boal writes that with Arena Conta Zumbi, Teatro de Arena "revalidated the struggle of the Blacks as an example of another that we must wage in our own time" (Theatre of the Oppressed 167). ${ }^{11}$ Boal directly linked the seventeenth-century Portuguese imperialist forces to the contemporary Brazilian dictatorship by basing a particular character's speech upon newspaper clippings of a speech delivered by Castello Branco to the Brazilian army regarding the military's responsibility to police "internal enemies" (TO 172).

Boal and Guarnieri made a similar allegorizing move with the musical Arena Conta Tiradentes (1967), which draws from national myths generated by the story of Joaquim José da Silva Xavier ("Tiradentes"), the eighteenth-century revolutionary considered to be one of the founders of the Brazilian nation. By using notable figures from Brazilian history to refer specifically to contemporary Brazilian politics, Boal created national allegories linked to Brazil, much like the allegories with one ultimate signification that Jameson and Winckelmann describe. As Sábato Magaldi writes of the two Arena Conta plays, "Os heróis históricos dos títulos serviam apenas para acobertar o exame da situação atual, exortando o público à resistência contra o regime iníquo imposto a população" (94). Indeed, even the titles of the plays, 'Arena tells the story of Zumbi/Tiradentes,' anchors them to a specific theatre group in the local setting of São Paulo.

While in his Arena Conta plays Boal nationalizes myth, in A Lua he mythologizes a man who transcends nationhood. Che's philosophy of proletarian internationalism meant that he was "at home" in any country waging a war against imperialist forces, particularly those of the United States. ${ }^{12}$ In 1968, the year after his death, Che Guevara was moving from man to myth. This was in large part because of a much publicized eulogy delivered by Castro at a memorial service for Che in Havana on October 18, 1967, during which Castro discredited the sentiments of 'imperialist enemies' who "think that by eliminating a man physically they have eliminated his thinking - that by eliminating him physically they have eliminated his ideas, eliminated his virtues, eliminated his example" (27). This speech is in fact one of the primary intertexts of the collage of speeches and writings that constitute A Lua, 
with the passage quoted above serving as a final exhortation to keep Che alive in memory and tribute. If, as Benjamin implies, allegory necessarily mythologizes by rescuing for eternity persons or things doomed to a transient existence (223), ${ }^{13}$ then Boal's allegorizing of Che participates in the mythologizing of the revolutionary leader. Several of the intertexts in A Lua then serve to globalize that myth.

Here it is necessary to provide a brief overview of the make up of the text, which could be considered an early precedent of documentary drama, the genre of dramatic writing that involves cutting and pasting together legal documents, interviews, and other dialogue culled from "real life."14 For the most part, A Lua follows the 'Joker' system (sistema coringa) that Boal elaborates in Theater of the Oppressed. In this system, the two most important functions are the protagonist and the Joker. As the character that spectators follow emotionally throughout the play, the protagonist elicits an empathetic response from the audience. The protagonist is thus Boal's way of balancing out the abstract nature of the Joker and the other characters of the piece, since highly abstract theatre can be unpalatable to theatre audiences (TO 180-81) ${ }^{15}$ In $A$ Lua, the protagonist is the Che character, referred to solely as "O Comandante." True to the function of Boal's protagonists, the Comandante is the only character played by the same actor throughout the play. His dialogue is culled from, among other texts, Guevara's good-bye letters to his parents and Castro upon leaving his government post in Cuba in 1965, his speech to the Tricontinental Assembly, and the final entry from his Bolivian diary, from which the title of the play is drawn: "Nós somos dezessete e caminhamos sob uma lua muito pequena. A caminhada foi perigosa e nós deixamos muitos traços pelo caminho" (Boal, A Lua 93). ${ }^{16}$ Among the exchanges featured in the scenes are Che's explanation of the necessity of guerrilla warfare to his soldiers, his efforts at persuading a peasant woman with goats and a rural schoolteacher that the poor need to revolt against their own impoverished conditions, and a prison scene wherein the Comandante confronts his soon-to-be-executioners. ${ }^{17}$

In Boal's system, the Joker performs the role of master of ceremonies, introducing scene segments and commenting upon the predicament of the protagonist and the actions of the other characters. Omniscient and detached from the play's action, the Joker often represents the point of view of the playwright or adapter (TO 181-82). In $A L u a$, the Joker, who is primarily the voice of Castro, dominates the prologue and the epilogue. The prologue is an excerpt from Castro's public announcement on Cuban radio and televi- 
sion on October 15, 1967, during which Castro confirmed that Che's death in Bolivia, heretofore considered mere rumor by the multitude of Che devotees worldwide, was "painfully true." 18 The Joker's part in the final exhortations is drawn primarily from Castro's eulogy to Guevara, including the much quoted appeal: "If we wish to express what we want the men of future generations to be, we must say, "Let them be like Che!" (Castro 28) ${ }^{19}$ Appearing intermittently in the intervening scenes between prologue and exhortation, the Joker in A Lua performs a role similar to that of the choral interludes of baroque German tragic drama. According to Benjamin, pronouncements made by the chorus inject wider significance into the actions of the main characters, which in turn enables allegory to emerge (192). Therefore, the Joker's commentary on Che's heroic actions in Bolivia moves Che, in Benjamin's terms, from the transient to the eternal.

The Joker's allegorizing of Che in A Lua works on a different level than in other Boal plays that function as national allegory. In contrast to Arena Conta Zumbi and Arena Conta Tiradentes, here Boal is not using intertexts that would be familiar only to a Brazilian audience. Instead, he draws from texts by Castro and Guevara that would have been intimately familiar to any member of the international socialist community or anyone who admired Che's ideology and revolutionary efforts. Castro's confirmation of Che's death, his eulogy to Che, and the excerpts from Che's Bolivia diary were particularly well circulated in the months following Che's death. ${ }^{20}$ Likewise, Che's 1965 address to the Tricontinental was especially well known because of its oft-quoted call for "two, three, many Vietnams" to be fought all over the globe (359). One of the properties of global allegory is this kind of wider intertextual accessibility, which turns the play into an ideoscape easily circulated to theatre groups that share the ideology espoused by the play. The allegory thus acts as a global call to action against government oppression, whether in the form of dictatorships or colonial control, rather than a defiance of one particular military dictatorship in Brazil.

Another part of the textual collage that globalizes the allegory of Che as the human potential for revolution is the excerpt from Neruda's Canto General that serves as the piece's dedication. Entitled "Toada de Manuel Rodriguez" after section XXV of Neruda's epic, the dedication is an abbreviated ode to the life, passion, and death of Manuel Rodriguez, a Chilean guerilla. Beginning with a rumor that the guerilla is galloping his way here,${ }^{21}$ the passage then relays all of the places the soldier has stopped along the way: "Pasando por Yancagua/por San Rosendo/por Cauquenes, por Chena/ 
por Nacimiento/por Nacimiento, ay, si, /desde Chiricue/de todas partes viene Manuel Rodriguez./Pasale este clavel/vamos con él' (Boal, A Lua 90, my emphasis). The dedication thus introduces a sense of movement to the piece that is reinforced by the staccato rhythm of the cueca, a Chilean national dance, which Neruda employs in this section of his epic in order to mythify Manuel Rodriguez's ventures (de Costa 137).

Interestingly, then, Boal draws from Neruda's mythologizing of Rodriguez, a figure from Chile's history, to begin a play that in turn mythologizes Che, suggesting that Che as allegory cannot be read in any singular national context. That the play concludes with an homage to Che drawn from Cubans (Castro) and Argentinians (Huasi and Cortazar) alike reinforces this idea, ${ }^{22}$ and perhaps suggests that the allegory gestures to all of Latin America. In fact, when the schoolteacher character asks the Comandante why he has come so far in order to fight in her country, he responds: "Bolívar disse que a nossa pátria é a América Latina" (96). However, the use of Che as the central figure in $A$ Lua links the allegory to Africa as well, since Che's intention in going to the Congo in 1965 was to incite a third anti-imperialist front that would complement similar sites of struggle in Latin America and Vietnam. ${ }^{23}$ The fact that the Che character embodies so many different geographical areas renders the allegory in $A$ Lua as complex as those employed by the baroque dramatists that Winckelmann bemoans: "In later times there arose the practice of bringing many concepts together, by means of just as many signs, in one single figure..." (Qtd. in Benjamin 186). The "many signs" brought together under the "single figure" of the Comandante in A Lua become road signs pointing to Chile, Argentina, Bolivia, and beyond.

Benjamin's response to Romantic critics such as Winckelmann is to evoke the image of ruins: "Allegories are, in the realm of thoughts, what ruins are in the realm of things" (178). For Benjamin, the idea of a ruin embodying traces of history in its eternal decay was the perfect analogy for allegory and its ability to merge history (in the case of $A$ Lua, the story of Che's demise) with thoughts and ideas that transcend the material world (such as socialist ideology). Yet Benjamin notes that successful allegories must "constantly unfold in new and surprising ways" (183). Theatrical productions are the means by which global allegories unfold, molding the allegory into a specific response to the political climate of a nation. 


\section{Brazil, 1968: A Feira Paulista de Opinião}

A Lua was Boal's contribution to the São Paulo Fair of Opinions, initiated in June of 1968 and organized by playwrights, composers, and visual artists from various cities in Brazil as a response to the increasing imposition of censorship onto the arts. Other contributors included Guarnieri, Jorge Andrade, and Bráulio Pedroso (Boal, Hamlet and the Baker's Son 26465). ${ }^{24}$ In a short introduction to Feira Brasileira de Opinião (1978), a published collection of some of the dramatic pieces featured, Ruth Escobar writes that the Fair "cumpre um papel importante no teatro no Brasil de hoje, acendendo a questão 'Quem somos, a que vimos, quem é nosso povo?'” (7). But that sense of weightiness is not necessarily borne out in critical overviews of Brazilian theatre, some of which, like Sebastão Milaré's "Apontamentos cronológicos de desenvolvimento da encenação no Brasil," do not even mention it. In short, any discussion of the Fair entails an unfortunate reliance upon one person's account of it (Boal's), and this article is no exception.

In his autobiography, Boal tells story after story about government censors, one of whom summoned a Port Alegre director to his office to request the presence of the author of Antigone in order to discuss some necessary changes to the script (Hamlet 262-63). In frustration, Brazilians artists decided to develop a "mural" of artistic responses to Brazil in 1968. ${ }^{25}$ For example, visual artists made works of art criticizing the dictatorship's propaganda about the "Brazilian Miracle," while playwrights wrote about the corrupt bourgeoisie, censorship, and inadequate medical treatment. David S. George characterizes the Fair as "equal parts wildly comic absurdism, melodrama, and didacticism," yet also notes that it was an important exception to the "panorama of mediocrity" that prevailed in the Teatro de Arena from 1966-71 (Modern Brazilian Stage 52). Written as a conclusion to the show, $A$ Lua, with its focus on guerilla warfare, was an appropriate addition to what was to become, as Boal puts it, the theatre community's guerrilla war (Hamlet 264).

Only fifteen of the 80 pages of the entire script for the Fair survived the censor. Nevertheless, the artists announced to the São Paulo community their intention to go ahead with the performance as an act of civil disobedience. The morning after, the theatre was surrounded by police, but the actors told the spectators to meet them at another São Paulo theatre, where the actors arrived singing songs banned by the censor. By the third day, with the military surrounding all of the theatres in São Paulo, the show relocated to a 
theatre in Santo André, where actors performed the whole script in defiance of censorship. Newspaper headlines announced "the Theatre's Guerilla War," while the actors entered a legal plea of habeas corpus (Hamlet 265-67). The next day, with all of Santo André's theaters surrounded, the group was finally able to stage the production because of a last minute "mandado de segurança" issued by a Judge. ${ }^{26}$ After that, the Fair participants staged the complete production in various sites.

Although the temporary legal license prevented the military police from taking any further legal actions, they began to respond with some surreptitious warfare of their own. At one of the performance sites, the Teatro Ruth Escobar, Chico Buarque's Roda Viva was being produced on another floor. That show became the target of a paramilitary attack (George, Modern Brazilian Stage 53), and Boal tells of sulphur bombs being thrown into the theatre. ${ }^{27}$ Although the attack was directed at the Roda Vida actors, the Fair participants aggressively rushed to their defense (Boal, Hamlet 267), and received some threatening letters themselves (George, Modern Brazilian Stage 53). When the Fair moved to a Rio theatre, a grenade was hurled onto the stage which, luckily, did not go off (Hamlet 268). Prepared for the worst, the Fair actors performed with guns on hand, engaging in target practice in theatre basements before the shows. Fortunately for Boal and company, 1968 was the year that students began to play an active role in demonstrations and protests against military repression of civil liberties (Dassin 114). In exchange for free admission to the Fair, students acted as security guards, searching spectators before they entered the theater and standing guard at the wings of the stage as actors went out to take their bows (Hamlet 268). The Fair was eventually shut down by the censors in December 1968, after the government announced a state of siege (George, Modern Brazilian Stage 53).

In Legislative Theatre, Boal writes that the Feira Paulista de Opinião "became a veritable trial of the local government" (226). This statement reveals how the production transformed the global into a national allegory. During performance, signs that signify globally within the text take on heightened local significance. For example, in a scene entitled "Diálogos em Busca da Verdade," the Comandante queries his captor: "Em que país amigo você aprendeu a combater?" The Captain's unfinished response is the only instance of English spoken within the play: "Of course...I..." (Boal, A Lua 94). In the text, the allusion to U.S. and CIA-trained military points not just to the Bolivian soldiers who captured Che but to similarly trained soldiers in other 
parts of the world, such as Vietnam, Uruguay, Honduras, Panama, Argentina and Chile. ${ }^{28}$ At the São Paulo Fair, however, this accusation became redirected to the interaction between the U.S. government and the Brazilian dictatorship, including perhaps the U.S.'s involvement with the 1964 coup that brought Castello Branco to power.

As an example of how a production aspect could assist in making the accusation specific to Brazil, consider the message of one of the visual displays at the Fair: a collage made out of colored wood that created the illusion of the Brazilian flag transforming into that of the United States (Hamlet $265)$. With the juxtaposition of the play text and the visual art, the global allegory of $A$ Lua metamorphosed into a national allegory for U.S.-aided military repression in Brazil. Further, the production itself generated an instance of national allegory: the account of Che's opposition to Bolivian military forces intent on repressing revolution became an allegory for the unyielding efforts of the Brazilian artists to stage the Fair despite overwhelming government resistance. In effect, the play condemned the actions of the Brazilian military police at the precise moment that grenades and sulphur bombs were being cast into theatres.

\section{Cape Verde, 1977: Festas de Independência de Cabo Verde}

When amateur theatre director Francisco Fragoso decided to produce A Lua in Cape Verde in 1977, he was already primed to receive the pro-Che Guevara message of Boal's play. Fragoso was a devout admirer of Amílcar Cabral, founder of the PAIGC political party in $1963,{ }^{29}$ and there was a direct link between Che's ideology and that of Cabral and the PAIGC. Not only did Cabral state that the PAIGC liberation movement was in part a defense of socialist countries worldwide, but the party also relied on support from socialist countries such as the Soviet Union, China, Czechoslovakia, and Cuba (Cabral 75). ${ }^{30}$ Fragoso, a surgeon by profession, knew Cabral personally while serving as a medical doctor for the guerilla party during the national liberation struggle, fought in Guinea-Bissau. This experience fostered a deep regard for both Cabral and Guevara (Fragoso, personal communication). The PAIGC became the governing party in Cape Verde shortly after independence was achieved in 1975, the same year that Fragoso founded the theatre group Korda Kaoberdi in Praia, Cape Verde's capital. ${ }^{31}$

As Korda Kaoberdi had already performed at the festivities commemorating the twentieth anniversary of the founding of the PAIGC, held in Guinea-Bissau in September of 1976 (Kondé 10), the group was a natural 
choice to perform for the independence day celebrations held in the city of Mindelo in July of 1977. Korda Kaoberdi participated at the invitation of the local government of São Vicente, the island on which Mindelo is located, because at the time Mindelo lacked a theatre group of its own (Fragoso, personal interview) ${ }^{32}$ A Lua was one of the three shows that Korda Kaoberdi performed for the event. In the remainder of this essay, I will discuss how the Che Guevara figure became an allegory for Amílcar Cabral in Korda Kaoberdi's production of $A L u a$, which is further evidence that global allegories become nationalized through production. Moreover, when considered in conjunction with the Brazilian staging, the Cape Verdean production reveals the critical difference between a state-sponsored political allegory and one that is state-censored. Korda Kaoberdi's 1977 Mindelo performances were pro-Amílcar Cabral, whether or not they were also overtly pro-PAIGC. ${ }^{33}$ However, the placement of the performances within the context of an independence day celebration promoted by the local branch of the PAIGC government party - at that time still deeply entwined with the memory of Cabral and the country's two-year-old independence - necessarily inflected the reading of the political allegory.

Striking similarities between Cabral and Guevara paved the way for the allegorizing of Che to be easily transformed into a nationalist commendation of Cabral. Guevara advocated worldwide revolution against imperialism; Cabral advocated revolution against colonialism in all of the former Portuguese colonies. ${ }^{34}$ Guevara helped Castro lead two dozen guerrilla fighters to victory against the armed forces of the Cuban dictator Fulgencio Batista in 1959. The guerilla army that Cabral and the PAIGC organized for Cape Verde and Guinea-Bissau defeated the Portuguese colonialist forces in 1974, even though the latter outnumbered them eight to one. ${ }^{35}$ Guevara wrote extensively about communism and organized Marxist education for the Cuban and Bolivian soldiers working under him; Cabral was a brilliant political and social theorist who adopted a Marxist-Leninist approach to class analysis in Africa (Chilcote 37). Further, there was a mutual admiration. In a 1969 interview, Cabral referred to "o grande Che Guevara," whose book Guerrilla Warfare was one of the primary texts the PAIGC used to train their own guerrilla soldiers (62). For his part, Che singled out the revolution in GuineaBissau as among the most successful of the anti-imperialist struggles on the African continent. ${ }^{36}$ Both became political martyrs as well: Che was executed in Bolivia in 1967; Cabral's 1973 assassination by a PAIGC insider was probably orchestrated by the Portuguese secret police (Chabal 133). 
Perhaps more important in terms of the circulation of the global allegory is the flow of ideoscapes, in the form of performance philosophies, between Boal and Fragoso. Boal's advocacy of a spectator-centered theatre had a profound impact on Fragoso (Branco 149). This is evident by the number of Boal quotes that pepper the journal documenting the activities of Korda Kaoberdi, Caderno "Korda Kaoberdi:" Ano de 1979-1980, published by Fragoso under the pen name Kwame Kondé in 1980. In fact, the quote that graces the end of the section on $A$ Lua is: "Todo o teatro é politico, ainda que não trate de Temas específicamente politicos. Dizer 'Teatro político' é um pleonasmo, como seria dizer 'homem humano"' (Boal qtd. in Kondé 22). Boal was inspired by Paulo Freire's notion of consciousness-raising through education, later explicated in Freire's Pedagogy of the Oppressed (1970). ${ }^{37}$ As the idea that theatre should awaken critical senses is present in Fragoso's writings as well (Kondé 5), one might trace a line of influence from Freire to Boal to Fragoso. Fragoso is an example of how ideoscapes are often circulated by ethnoscapes, the movement of people across the globe (Appadurai 33). Educated in Portugal and France, Fragoso transported to Cape Verde theatre ideologies to which he was introduced while abroad (Branco 149). Fragoso encountered the text of $A$ Lua in a bulletin published by CITAC (Círculo de Iniciação Teatral da Academia de Coimbra) in Portugal (personal communication).

Boal's efforts at producing a Brazilian national theatre at Teatro de Arena are mirrored in Fragoso's intent to create a theatre reflecting a uniquely Cape Verdean culture (Kondé 6). To this end, Fragoso and his actors drew upon batuko and tabanka, two music and dance styles considered indigenous to Santiago, the island on which Praia is located, when creating Korda Kaoberdi's first two productions, Preto Toma Tom and Historia dum Pobo. ${ }^{38}$ However, the 1977 productions of A Lua signified a shift toward a theatre with, according to Fragoso, a more "universal" dimension, as opposed to Korda Kaoberdi's previous two pieces, which he calls "genuinamente caboverdianos." In the commentary on A Lua in Caderno "Korda Kaoberdi," Fragoso explains that he wanted the group to begin performing "peças não nacionais" in order to explore plays with aesthetic styles perhaps unfamiliar to Cape Verde, yet with themes that nonetheless resonated with a Cape Verdean social reality (Kondé 20-21). The Mindelo production of $A$ $L u a$, however, demonstrates that even a "non-national" play can make a decidedly nationalist statement in performance. 
The 1977 independence celebrations occurred at a time when public confidence in the PAIGC government party was waning. During the late 1970s, the PAIGC began arresting dissidents from opposition political parties. This followed from a law that the PAIGC passed in 1975 granting their national security agency the power to detain people without charging them first (Lobban 111). ${ }^{39}$ The dissidents in question regarded PAIGC government as pro-Soviet and an impediment to substantial financial aid from the U.S, yet even Cape Verdeans uninvolved with the opposition groups took note of the PAIGC's increasingly repressive measures (Lobban 112).$^{40}$ It is significant that Korda Kaoberdi performed $A$ Lua at a time when there was a growing apprehension about the PAIGC's socialist connections. A piece celebrating the socialist figure of Che Guevara could thus be read as proPAIGC statement, whether or not Fragoso intended this, especially since the production turned Che into an allegorical figure for Cabral.

Korda Kaoberdi's production of $A$ Lua opened with the recitation of a poem written by Fragoso entitled "Homenagem a Che Guevara." In an article about Korda Kaoberdi's independence day performances reprinted in Caderno "Korda Kaoberdi," a reviewer from an Angolan journal relates that the production of $A$ Lua was plagued by problems with sound equipment, which made it harder for those not familiar with the story to understand (qtd. in Kondé 24). Thus, the intertextuality of $A$ Lua would not have had the same effect in Cape Verde that it did in Brazil ten years earlier. Boal has explained that he incorporates well-known speeches and writings into his plays so that spectators can immediately grasp the political implications of the play, which in turn elicits a critical response from them (TO 166). Apart from the fact that the Cape Verdean audience members were prevented from hearing the dialogue of the play very well, they would likely have been less familiar with the intertexts. The speeches by Castro and Che that were perhaps engrained in the public mind when Brazilian audiences saw the play in 1968, only a year after Che's death, were but a distant memory in 1977, especially to a Cape Verdean audience distant from Latin America geographically as well. Therefore, the Mindelo audience only saw a production paying tribute to Che, whom they would have at the very least associated with socialist revolt.

Korda Kaoberdi performed three shows for the celebrations: Preto Toma Tom, A Lua and Storia dum Pobo. The last was a re-telling of the history of the Cape Verdean people, featuring scenes enacting their life on mainland Africa before the slavery era, their ensuing forced removal to the 
Cape Verde islands by Portuguese traders, their harsh treatment by the Portuguese during colonization, and their recent victorious revolt against the colonial forces (Kondé 18). The reviewer of the Mindelo production writes that during the last act of Storia dum Pobo, the image of Cabral was projected onto the back of the scenery, at which point the public rose to their feet and applauded for several minutes (cited in Kondé 24). The message of the production was clear: Cabral is the man responsible for liberating the Cape Verdean people from centuries of oppression. As Cabral was also linked inextricably with the PAIGC party, this rousing homage to Cabral made a critical political intervention at a time when the party's popularity was in decline. Korda Kaoberdi made the spectators complicit with this political message by soliciting their corporeal involvement, not only by eliciting a standing ovation for Cabral but also by inviting audience participation in the exuberant tabanka march that concluded Storia dum Pobo. ${ }^{41}$ In fact, when Korda Kaoberdi staged $A$ Lua, the group likely involved the audience to a greater extent than Boal did with his 1968 staging. In his article on Boal, George emphasizes that despite Boal's theorizing about Theatre of the Oppressed, his regular productions have been executed with the fourth wall firmly intact (40). Korda Kaoberdi, however, performed scenes from each play right in the middle of the audience (Branco 158), and A Lua was no exception (personal interview with Fragoso).

Previously I argued that in the São Paulo Fair of Opinions, the juxtaposition of the Brazilian/American flag visual art with the production of $A$ Lua helped to transform a global allegory into a national allegory for government corruption in Brazil. In Cape Verde, the juxtaposition of Storia dum Pobo with $A$ Lua resulted in a nationalist message that did more than just demonstrate support for PAIGC: it mythologized Cabral in much the same way that the text of $A$ Lua helped to mythologize Che after Castro's eulogy had turned him into a public icon. Since Cabral was already a public icon in Cape Verde, the independence day celebrations were an opportunity to rescue him for eternity, to use Benjamin's terms (223), by linking him allegorically with Che. The homage to Cabral following closely on the heels of a tribute to Che, a historical figure with remarkable parallels to Cabral, linked the two men together in such a way that Che's already mythified struggle against imperialism in South America became an allegory for Cabral's more recent revolt against Portuguese colonialism. Thus, just as Neruda's mythologizing of Manuel Rodriguez in the text of $A$ Lua in turn mythologizes Che, the summoning of Che as myth into Cape Verde's independence cel- 
ebrations makes a move to transform a national hero, Cabral, into a largerthan-life figure comparable in stature to Guevara.

Another production aspect that nationalized the global allegory of $A$ $L u a$ was the performance space itself. Korda Kaoberdi's three productions were performed on the small stage in Eden Park, the cine-teatro in Mindelo that had long served as a space for musical performance, movies, meetings, and conferences. ${ }^{42}$ Significantly, Eden Park was the very space where, in June of 1974, PAIGC representatives met to approve a document later cabled to then Portuguese President António Spínola, who at that point insisted on retaining Cape Verde as a province of Portugal. The document generated at Eden Park demanded independence for Cape Verde and declared the PAIGC to be the only legitimate political representative of the country (Davidson 119). Thus, Eden Park was what Joseph Roach might call a "vortex of behavior" (28-29), powerfully infused with the memory of PAIGC nationalism. The historical significance of the performance space, together with the allegorizing of Che as Cabral, turned the Mindelo independence day performance of $A$ Lua into an affirmation of the PAIGC's legitimacy as the ruling party in Cape Verde.

\section{Conclusion}

A comparison of two productions of $A$ Lua separated in time by nine years and in space by the Atlantic Ocean illustrates the particular potency of global allegories: the same allegory that helped to put the Brazilian military dictatorship on trial in 1968 served as an encomium for the Cape Verdean government in 1977. This was because the individual productions, conditioned by the local political climates, determined which "role" in the allegory became assigned to the government party. While the production for the São Paulo Fair of Opinions clearly aligned the Brazilian dictatorship with the CIAdirected Bolivian military, the obvious antagonists of $A$ Lua, the Mindelo independence day production aligned the Cape Verdean government with Che, the play's hero.

Clearly, the circulation of political allegory through the passing of dramatic texts from director to director is one way in which theatre participates in a global cultural economy. However, the fact that global allegories are potentially transformed through production into national allegories also supports the idea put forth by globalization theorists that globalization does not equal homogenization. Appadurai and Roland Robertson both argue that even though trends in music, film, and theatre often emanate from the West 
(more specifically, the United States), these "cultural messages" are nonetheless indigenized, meaning that they are received and interpreted differently everywhere (Appadurai 32; Robertson 38). A Lua is one example of how productions may indigenize global allegories, since political allegory signifies differently to different audiences. Yet because it demonstrates that theatrical trends do not always originate in the West and trickle out to nonWestern countries, the case study of A Lua makes another crucial intervention in the discourse about a global culture economy. As is clear from productions of A Lua mounted in Brazil and Cape Verde, ideoscapes circulated in the form of dramatic texts can also circumvent the West altogether, destabilizing its privileged position as the "cultural center" of a globalized world.

\section{Northwestern University}

\section{Notes}

1 The Origin of German Tragic Drama (223).

2 "Trajetória de uma Dramaturgia," Teatro de Augusto Boal, vol. 1 (12).

3 Caderno "Korda Kaoberdi": Ano de 1979-1980 (19).

4 I am much indebted to Ana Elena Puga for her invaluable guidance throughout the writing and revising process. Her article on abstract allegory (cited here), also a response to Jameson, helped me to clarify my own thinking about global allegory. Thanks also to Susan Manning for reading an earlier draft and providing feedback, and to Sandra L. Richards, who reads all of my work with such critical attention. Also thanks to an anonymous reviewer from the Latin American Theatre Review for feedback and to editor George Woodyard for pointing me in the direction of David George's illuminating article on Boal (cited here), which in turn pointed me in the direction of other important sources on Boal. I am especially grateful to Dr. Francisco Fragoso for his time during July of 2004 and for his enthusiastic support of this article. The interview with Dr. Fragoso in Lisbon was part of a summer research trip made possible by two grants from Northwestern University's Program of African Studies.

5 Hereafter referred to as $A$ Lua for brevity.

6 The authors of Brasil: Nunca Mais, an account of torture under dictatorship from 1964-1985, hold the U.S. government partially accountable for the 1964 coup against President João Goulart. As proof of this, they note that U.S. Lieutenant Colonel Vernon Walters supplied arms to one of the coup organizers, General Carlos Guedes (47). See the English translation, Torture in Brazil (47).

7 In Uruguay, the Tupamaros, a leftist group that subscribed to Guevara's call for worldwide revolution, were pursued by the government since the group's inception in the early 1960s. The military staged a coup in 1973 and remained in power until 1984. See Weschler, $A$ Miracle, A Universe (101-31).

8 In Hamlet and the Baker's Son, Boal does take credit for creating the coringa system but acknowledges its Brechtian roots by characterizing it as "Verfremdungseffekt taken to its ultimate consequences" (242). 
9 For a brief summary of Boal's theatre philosophy and career trajectory, see In Contact with the Gods? Directors Talk Theatre (16-20), eds. Maria M. Delgado and Paul Heritage. For a more extensive, personal account, see Boal's recently published autobiography, Hamlet and the Baker's Son: My Life in Theatre and Politics (2001).

${ }^{10}$ Boal characterizes the years $1958-1964$ as follows: "It was a long period during which the Arena Theater closed its doors to European playwrights, regardless of their high quality, opening them to anyone who wished to talk about Brazil to a Brazilian audience" (Theatre of the Oppressed 162).

"Hereafter cited as TO.

12 See Che's message to the Organization of Solidarity with the Peoples of Asia, Africa, and Latin America (the Tricontinental), published in 1967 in the inaugural edition of the magazine Tricontinental and reprinted in several anthologies of Che's writing, including Che Guevara and the Cuban Revolution: Writings and Speeches of Ernesto Che Guevara, ed. David Deutschmann.

${ }^{13}$ In this passage Benjamin explains that allegory was the means by which the ancient gods survived the rise of Christianity. Although supposedly obviated by the pervasive monotheism of Christianity, the gods survived as embodiments of ideas in the writings of Horace, Ovid, Nonnon, and Claudius Claudianus.

${ }^{14}$ Documentary drama has recently been popularized by the contemporary playwrights Emily Mann and Anna Deveare Smith.

is With the Joker/protagonist combination, Boal follows Brecht's idea that acting should consist of a melding of emotional distance and empathy, the "tussle and tension of the two opposites" (Brecht 278).

${ }^{16}$ See the entry dated October 7 in Che's Bolivian diaries, reprinted in Mary-Alice Waters' edited version The Bolivian Diary of Ernesto Che Guevara (295).

${ }^{17}$ I have not been able to trace all of the intertexts that constitute the Comandante's dialogue. Some of the exposition on guerilla warfare comes from Che's speech to the Tricontinental. I presume the remainder comes either from his book Guerilla Warfare or his memoirs from the Cuban revolution. The dialogue in the prison scene is probably recreated from newspaper reports about Che's assassination. That of the scenes featuring the old woman with the goats and the schoolteacher was probably based on accounts of meetings with these people found in the September 22 and October 7 entries of Che's Bolivian diaries.

18 While I have not been able to locate this speech in its entirety, it is excerpted in a New York Times article dated October 16, 1967, entitled "Castro Says Death of Guevara is 'Painfully True."' In A Lua, the Joker's opening line is: "Eu devo começar dizendo que chegamos à conclusão de que a morte do Comandante é dolorosamenta certa" (89).

${ }^{19}$ In $A$ Lua this reads: "Se quisermos expressar como desejamos que sejam nossos companheiros, devemos dizer: que seja como ele! Se quisermos expressar como desejamos que sejam os homens das gerações futuras, devemos dizer: sejam como ele. Se quisermos expressar como queremos que se eduquem nossos filhos, devemos dizer sem vacilação de nenhuma índole. Queremos que se eduquen com o seu espírito" (97).

${ }^{20}$ Passages from the Bolivian diary were read in the much-publicized trial of French journalist Régis Debray in November of 1967 , just one month after Che's assassination (Waters 37).

21 "Señora dicen que donde/mi padre dice dijeron/el agua y el viento dicen/que vieron al guerrillero" (Boal, A Lua 90). Boal has taken this directly from Neruda's Canto General but I quote from Boal's text, the only part of the play written in Spanish. See also Jack Schmitt's English translation of Canto General (108-09).

${ }^{22}$ I have not been able to locate the exact texts by Huasi and Cortazar that Boal uses in A Lua. However, both writers were enamored of Che's revolutionary example. Cortázar wrote 
a short story entitled "Reunión" about Che's landing in Cuba and journey towards the mountains to meet Castro to start the revolution (neither Che nor Castro are actually named in the story). Both Huasi and Cortazar wrote poems dedicated to Che, reprinted in Poemas al Che, edited by Ambrosio Fornet and Winston Orrillo.

${ }^{23}$ See the quote from Victor Dreke, a Cuban revolutionary who accompanied Che to the Congo, in Richard Gott's introduction to The African Dream: The Diaries of the Revolutionary War in the Congo (xxiv).

${ }^{24}$ Hereafter cited as Hamlet.

${ }^{25}$ See Legislative Theatre (225-26) and Hamlet and the Baker's Son (264-68). My account of the Fair is drawn primarily from these two sources.

${ }^{26}$ See "Trajetória de uma Dramaturgia" (13) and Hamlet and the Baker's Son (267). In the latter source, Boal relates that the judge who issued the temporary license was later arrested for being a part of a secret guerrilla organization.

${ }^{27}$ Milaré corroborates this: "Ameças de bombas, invasões aos teatros e sequestros de atores de Roda Viva (peça de Chico Buarque dirigida por Zé Celso) estabelecem o clima de absoluto insegurança" (21).

${ }^{28}$ For an account of some of the notorious international attendees of United Statessponsored war colleges, including the School of the Americas, see Weschler, A Miracle, A Universe (118-19).

29 Partido Africano da Independência da Guiné e Cabo Verde.

${ }^{30}$ Castro was a staunch supporter of the PAIGC anti-colonial struggle, and Cuba even served as a training ground for Cape Verdean guerrilla soldiers before independence (Davidson 17).

31 "Korda Kaoberdi" is Cape Verdean Crioulo for "Awaken Cape Verde." Crioulo derives from Portuguese and a number of West African Senegambian languages (Lobban and Lopes 67).

32 Today, Mindelo plays an integral role in Cape Verdean theatre, as it is home to the annual Mindelact International Theatre Festival.

${ }^{33}$ I am inferring that, at least at the time of the 1977 independence celebrations, Francisco Fragoso was a PAIGC supporter. This is suggested by the number of Cabral quotes that he reprints in Caderno "Korda Kaoberdi:" Ano de 1979-1980, the fact that he served as a doctor for the PAIGC during the liberation movement, as well as the fact that his theatre group performed for the PAIGC's $20^{\text {th }}$ anniversary celebrations in Guinea-Bissau in 1976. However, it seems that the relationship became more complicated as time went on. Fragoso met with a representative from Cape Verde's Ministry of Culture in 1982 to ask for increased support for Korda Kaoberdi, and was told that the government had only a limited budget for all of Cape Verdean cultural activities (personal interview, 2004). Fragoso left shortly afterwards for Lisbon, where he continues to practice medicine. João Branco asked Fragoso in a 2004 interview whether or not the PAIGC party forced Fragoso to leave the country in 1982, as there was some talk of Fragoso being a subversive. Fragoso replied: "Não foi o partido que me fez. Eu é que contribuí para o PAIGC. Já estava preparado. Ninguém me doutrinou" (qtd. in Branco 160). Branco also explains that the political party might have become wary of Korda Kaoberdi's dominance of the theatre scene, since the PAIGC wanted to centralize the country's cultural initiatives in JAAC (Juventude Africana Amílcar Cabral), the official youth group of the PAIGC party (159).

${ }^{34}$ See especially Cabral's short essay, "As caracteristicas Essenciais do Nosso Tempo. A Agonia do Imperialismo. O Caso Português," in Guiné-Bissau: Nação Africana Forjada na Luta (13).

${ }_{35}$ See Basil Davidson's compelling account of the PAIGC victory in The Fortunate Isles: A Study in African Transformation (61-126). 
36 See "Voluntary Work is a School for Communist Consciousness" (243) and "Vietnam and the World Struggle for Freedom" (353), in Che Guevara and the Cuban Revolution.

37 See the chapter in Boal's Legislative Theatre entitled "Paulo Freire, my last father."

38 The term 'indigenous' is actually not quite appropriate for the Cape Verde Islands, as the isles were unpopulated when Portuguese traders first brought Africans over from the mainland in the fifteenth century. However, I use the term because batuko and tabanka both developed on Santiago during the ensuing years of creolization between the Portuguese and the Africans. (Lobban 111).

39 The national security agency was called DiNaS, Direç̧ão Nacional de Segurança

40 The opposition parties that Lobban mentions are the UCID (União Caboverdeana para A Independente e Democrátia) and the UPICV (União das Populações das Ilhas de Cabo Verde).

${ }^{41}$ In a description of Storia dum Pobo included in Caderno "Korda Kaoberdi," Fragoso writes that the play concludes with a tabanka procession (18). In the article about the Mindelo production, the reviewer describes the final moment of the production as a "cena de força extraordinária, que confundiu actores com público e que consagrou a alegria popular pela libertação" (24).

42 I obtained this general information about Eden Park from the official website of Associação Mindelact, organizer of Cape Verde's annual international theatre festival, Mindelact. The association awarded their annual "Prémio de Mérito Teatral" to cine-teatro Eden Park in 2004: http://www.mindelact.com/destaque.htm, accessed on 10 June 2004.

\section{Works Cited}

Ahmad, Aijaz. In Theory: Classes, Nations, Literatures. New York: Verso, 1992.

"Allegory." The Oxford English Dictionary. $1^{\text {st }}$ ed. 1888.

Appadurai, Arjun. Modernity at Large: Cultural Dimensions of Globalization. Minneapolis: U. of Minnesota Press, 1996.

Benjamin, Walter. "Allegory and Trauerspiel." The Origins of German Tragic Drama. Trans. John Osborne. London: Verso, 1998.

Boal, Augusto. Hamlet and the Baker's Son: My Life in Theatre and Politics. Trans. Adrian Jackson and Candida Blaker. New York: Routledge, 2001. . Legislative Theatre: Using Performance to Make Politics. Trans. Adrian Jackson. New York: Routledge, 1998.

. A Lua Pequena e a Caminhada Perigosa. Teatro de Augusto Boal. Vol. 2. São Paulo: Editora Hucitec, 1990.

. Theatre of the Oppressed. Trans. Charles A. and Maria-Odilia Leal McBride.

New York: Theatre Communications Group, 1985.

. "Trajetória de uma Dramaturgia." Teatro de Augusto Boal. Vol. 1. São Paulo:

Editora Hucitec, 1986.

Branco, João. Nacão Teatro: História do Teatro em Cabo Verde. Praia, Cabo Verde: Instituto da Biblioteca Nacional e do Livro, 2004. 
Brecht, Bertolt. Brecht on Theatre: The Development of an Aesthetic. Ed. and trans. John Willett. New York: Hill and Wang, 1998.

Cabral, Amílcar. Guiné-Bissau: Nação Africana Forjada na Luta. Lisboa: Nova Aurora, 1974.

Castro, Fidel. "Che's Enduring Contributions to Revolutionary Thought." Introduction. Che Guevara and the Cuban Revolution. By Ernesto Che Guevara. Ed. David Deutschmann. Sydney: Pathfinder/Pacific and Asia, 1987.

"Castro Says Death of Guevara is 'Painfully True."' New York Times 16 Oct. 1967: 4.

Chabal, Patrick. Amillcar Cabral: Revolutionary leadership and people's war. Cambridge: Cambridge U. Press, 1983.

Chilcote, Ronald H. Amilcar Cabral's Revolutionary Theory and Practice: A Critical Guide. Boulder: Lynne Rienner, 1991.

Dassin, Joan, ed. Torture in Brazil: A Report by the Archdiocese of São Paulo. Trans. Jaime Wright. New York: Vintage, 1986.

Davidson, Basil. The Fortunate Isles: A Study in African Transformation. London: Hutchinson, 1989.

De Costa, René. The Poetry of Pablo Neruda. Cambridge, MA: Harvard UP, 1979.

Delgado, Maria M. and Paul Heritage, eds. In Contact with the Gods?: Directors Talk Theatre. New York: Manchester UP, 1996.

Escobar, Ruth, ed. Feira Brasileira de Opinião. São Paulo: Global Editora, 1978.

Fornet, Ambrosio and Winston Orrillo, eds. Poemas al Che. Lima: Editorial Causachun, 1972.

Fragoso, Francisco. "Re: Resposta." E-mail to the author. 28 May 2005.

. Personal interview, 27 July 2004, Lisbon.

George, David S. The Modern Brazilian Stage. Austin: U. of Texas Press, 1992.

."Theatre of the Oppressed and Teatro de Arena: In and Out of Context." Latin American Theatre Review 28 (1995): 39-54.

Gott, Richard. Introduction. The African Dream: The Diaries of the Revolutionary War in the Congo. By Ernesto Che Guevara. Trans. Patrick Camiller. New York: Grove, 1999.

Guevara, Ernesto Che. The Bolivian Diary of Ernesto Che Guevara. Ed. Mary-Alice Waters. New York: Pathfinder, 1994.

. Che Guevara and the Cuban Revolution. Ed. David Deutschmann. Sydney: Pathfinder/Pacific and Asia, 1987.

Jameson, Fredric. "Third-World Literature in the Era of Multinational Capitalism." Social Text 15 (1986): 65-88.

Kondé, Kwame (Francisco Fragoso). Caderno "Korda Kaoberdi": ano de 19791980. Praia: Imprensa Nacional, 1981.

Larkin, Brian. "Indian Films and Nigerian Lovers: Media and the Creation of Parallel Modernities." Africa 67 (1997): 406-37. 
Lobban, Richard. Cape Verde: Crioulo Colony to Independent Nation. Boulder: Westview, 1995. and Marlene Lopes. Historical Dictionary of the Republic of Cape Verde: third edition. Metuchen, N.J.: Scarecrow, 1995.

Magaldi, Sábato. "O Texto no Moderno Teatro Brasileiro." Setepalcos 3 (1998): 8898. Reprinted from Panorama do Teatro Brasileiro, 3rd ed. (São Paulo: Global Editora, 1997).

Meade, Teresa A. A Brief History of Brazil. New York: Facts on File, 2003.

Milaré, Sebastião. "Apontamentos cronológicos do desenvolvimento da encenação no Brasil." Setepalcos 3 (1998): 17-22.

Neruda, Paulo. Canto General. Trans. Jack Schmidt. Berkeley: U of California P, 1991.

Puga, Ana Elena. "The Abstract Allegory of Griselda Gambaro's Stripped (El despojamiento)." Theatre Journal 56 (2004): 415-428.

Roach, Joseph. Cities of the Dead: Circum-Atlantic Performance. New York: Columbia UP, 1996.

Robertson, Roland. "Glocalization: Time-Space and Homogeneity-Heterogeneity." Global Modernities. Eds. Robertson, Mike Featherstone, and Scott Lash. London: Sage, 1995.

Weschler, Lawrence. A Miracle, A Universe: Settling Accounts with Torturers. New York: Pantheon, 1990. 